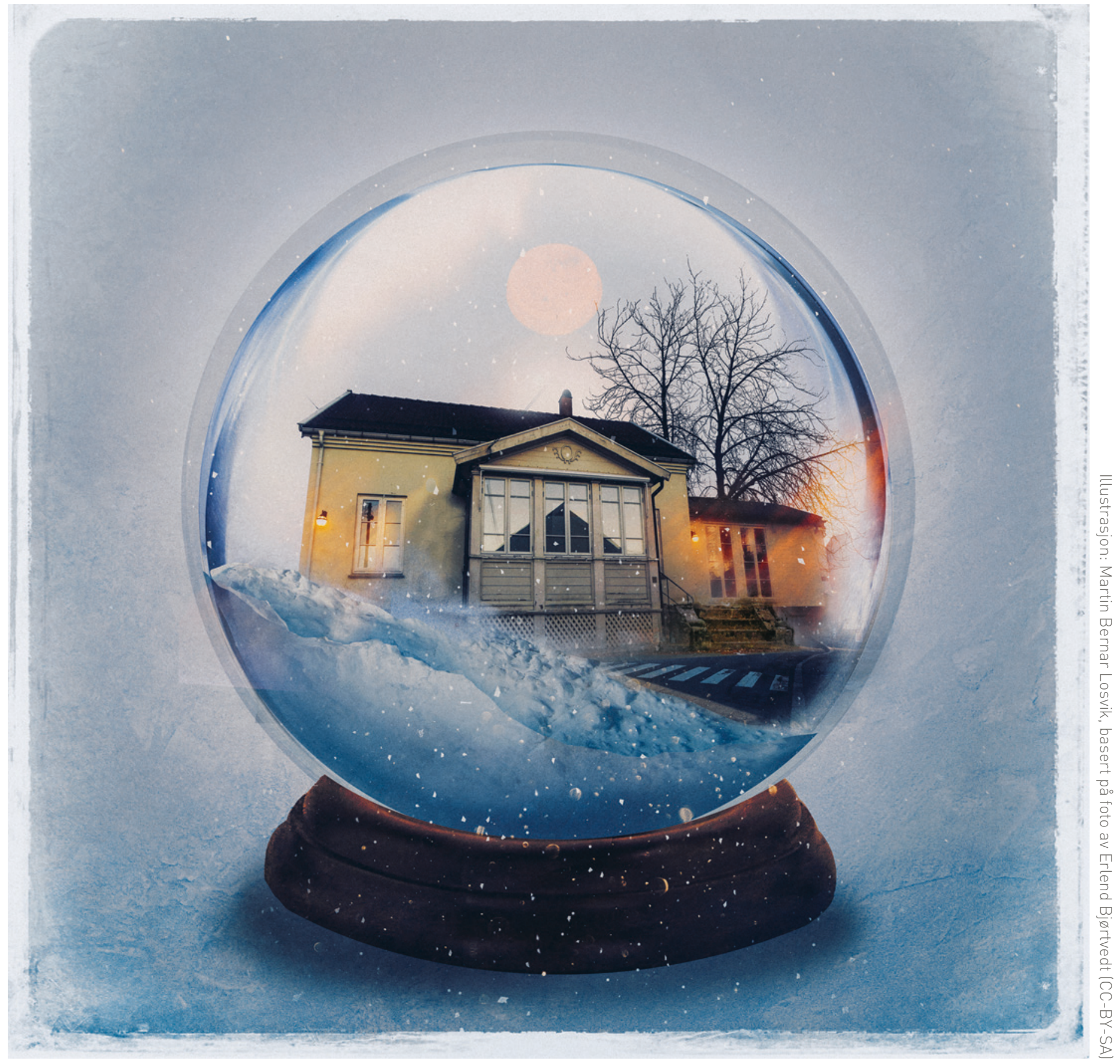

\title{
Røa legesenter (RøaLegene)
}

- Røa ligger nord for Ullernåsen og øst for Lysakerelva i bydel Vestre Aker i Oslo. Navnet Røa stammer fra norrønt og betyr «rydningene». Her jobber tre leger, en sykepleier og en helsesekretær. 